\title{
Interview with Akira Kurosawa
}

\author{
By Fred Marshall
}

Spring 1993 Issue of KINEMA

\section{THE EMPEROR OF FILM: NO, NOT YET!}

Fred Marshall speaks with Akira Kurosawa about his new film Madadayo (No, Not yet!).

"When I make a film like this, it makes me so happy," said the "Emperor of Celluloid" Akira Kurosawa upon the completion of his latest motion picture Madadayo which is to celebrate his Silver Jubilee of filmmaking. Madadayo is Kurosawa's thirtieth motion picture, and at a special press conference in Tokyo's Capitol Hotel, the director went on record to say that at 83 , he still has no other intentions then to make films. Madadayo was completed at the end of 1992; it is to be released worldwide after its Tokyo premiere in Tokyo in the first half of 1993.

Location shooting was done in Gotemba city, about 145 kilometres west of Tokyo, where sets showed the burnt homes and devastation of postwar Japan. In addition, huge open sets were constructed at the Toho Kinuta Studio in Tokyo, where Japan of the 1940s reappeared as sets were built representing typical town and street scenes of that era. During the production, Kurosawa received the fourth World Cultural Prize in the theatre/motion picture category.

The film's story focuses on the relationship between Hyakken Uchida (1889-1971) and his students. In 1943, Uchida leaves his teaching position at the University lo concentrate on his writing career. With his house burnt down in an air-raid, Uchida had to lead an impoverished life in a tiny hut. Despite this, his free spirit was never crushed and he surprised all around him with his out-spoken tongue. His students eventually held birthday parties for him which became more and more pompous with the passing years. The event was named "Mahda-kai" (literally: "not yet?"), -- "are you ready to go to the other world?" -- "Madadayo" (No, not yet)...

Marshall: Why are you nicknamed "Emperor?"

Kurosawa: It was given to me by the journalists; they like this nickname.

Why didn't you become a painter?

I couldn't pass my examination.

What is your favourite film?

Some people say it was Seven Samurai. It happened during the period I was extremely popular. However, it is not my personal favourite. To give birth to a work is to enlarge upon an idea which grows. It's difficult to say which one of my films is my favourite. I'd like to say, all my films come to life at one stage or another.

\section{What type of film do you like to make most?}

I never film what I don't want. I am not interested in making films where I am forced to raise money. Whether it's good or not, one must be strong. The film maker must believe in something, be honest with himself, and be objective in his job. The producer must give money to the film maker, so that the film maker has to believe that his producer will also believe in his creativity.

\section{How do you go about dealing with Truth?}

I must find a way to put it across for the most part. It's difficult to raise money by speaking the truth. However, it has been easier to depict Japanese history and express its cultural values.

\section{Why do you not give editorial credits on your films?}

Working by myself means that its fundamental. I do everything. It is part of my work as a director. I edit my rushes the day after I shoot them. I am different from others. I prefer to do it this way to avoid any last minute decisions before printing. It's more effective to edit with a fresh feeling. It's easier to obtain a final balance with correct editing. I take about two hours maximum to edit every day of shooting.

\section{How long is your filming period?}


I do my work over an eight-month period. I do not shoot every day. I use three cameras to work on each scene. I rarely repeat my shots and cuts. Sometimes I can make one in sixteen minutes without stopping.

How important is the scenario? How important are the actors?

The most important part of my film is the scenario for without a good script, actors are not much use. Non-professional actors can also play well. I expect my actors to be natural.

\section{What about your personal likes?}

I enjoy sports, watching films and reading. I live in Tokyo with my wife.

How important is the use of opticals in your films?

They are an important way of expressing visual effects. In my recent film I have used many of them. CBS Sony was most cooperative in helping me to put across certain points that I wished to develop in Hi-Vision technique. This technical process will help the industry in the long run and it is an excellent way to elaborate on technical effects. Of course it will take time to perfect, but I believe this new technique is very advanced and will definitely be an important part of our industry, in the years to come.

Do you use the High-Definition technology?

HDTV is very useful for special purposes, but the camera can capture nuances -- like human eyes -- which high definition cannot.

\section{Do you have any plans for the future?}

I suppose one of my long life ambitions is to make a film on the life of painter Vincent Van Gogh. Perhaps, I may work on this project in my remaining years, if it's meant to be.

Why haven't you used Toshiro Mifune in your last four films?

Toshiro Mifune is a great actor. He gave me his best work in my film Red Beard when he was at his peak. We are still very good friends, and though I have not used him recently, I have great respect for him.

What is your secret in working with actors?

I rehearse and prepare then. It takes eight months to prepare, so they can get involved and understand their character and develop interest in their interpretation. It takes time to develop a character. There is no secret. It first requires patience.

When asked about his new film and if he has changed his style:

I am not changing my form of expression.

When queried as to the nature of film:

When you make a film, you are one with the main character in the film -- laughing, crying, suffering together... that is film.

If you have power to influence your society an change it, how would you do about it?

I would do my best to take advantage of my creative abilities as an artist. I am happy I have the chance to express myself. I feel responsible, truthful and honest toward my profession and I am aware of this. I have no secret. I am first dealing with Japanese society and trying to be frank, in dealing with our problems. I hope you will understand this about me, when you go to see the film. As a story teller, I have no secrets.

\section{What is your new film Madadayo about?}

Madadayo is a film that describes a heart-warming and pleasant relationship between Professor Hyakken Uchida and his former students. There is something very precious, which has been all but forgotten. The enviable world of warm hearts. I hope that all the people who have seen this moon picture will leave the theatre feeling refreshed with broad smiles on their faces.

\section{Author Information}

Fred MARSHALL (d. 2003) wrote for the Variety International Film Guide. He was also the managing director/distributor of Cine Video, a Thailand-based 16mm art film library which supplies films to East Asia and made documentaries, among them Demons of Paradise. 


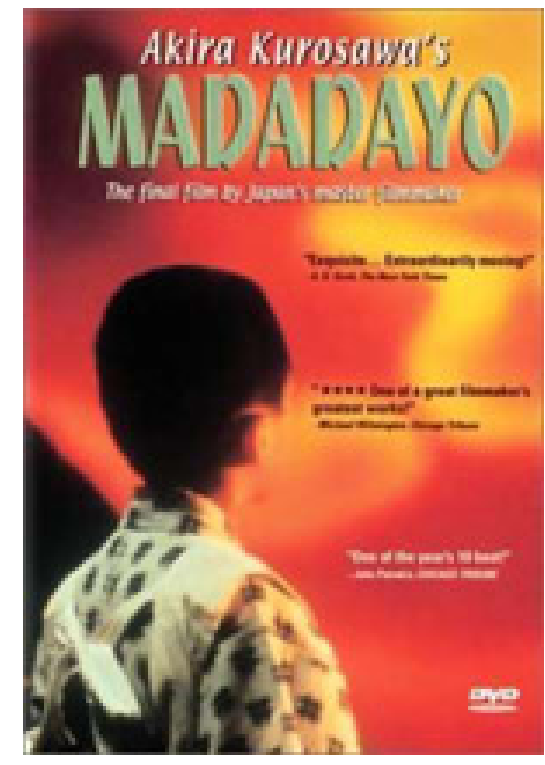

Figure 1: Madadayo (publicity poster) 